\title{
PENGARUH PENERAPAN MODEL PEMBELAJARAN TERHADAP SIKAP RELIGIUS SISWA PADA MATA PELAJARAN PENDIDIKAN PANCASILA DAN KEWARGANEGARAAN
}

\author{
Emi Ramdani, Marzuki \\ Pascasarjana Universitas Negeri Yogyakarta \\ Jl. Colombo No.1, Karang Malang Yogyakarta \\ Email: emiramdanii@gmail.com,marzuki@uny.ac.id
}

\begin{abstract}
: this article aims to describe the effect of applying learning models (discovery learning, problem-based learning, and project-based learning) for students' religious attitudes. The study used a quantitative approach, that a sample of 120 junior high school students in the Bantan District. Data collection using a questionnaire with 72 questions. Data analysis uses multiple linear regression. The results of the study indicate that the application of the discovery learning model and project-based learning have very high frequencies. The problem-based learning model has a high frequency. The learning model which has the greatest influence on the religious character of students is discovery learning with a sig value of $0.000<0.05$ and a calculated $\mathrm{t}$ value of 5.38 $>1.98$. The second sequence is project-based learning with a sig value of $0.001<0.05$ and $t$ value of $3.32>1.98$. The problem-based learning is in third place with a sig value of $0.01<0.05$ and $t$ value of $2.63>1.98$.
\end{abstract}

Keywords: character education, civic education, discovery learning, problembased learning, project-based learning

\begin{abstract}
Abstrak: tujuan penulisan artikel ini adalah untuk mendeskripsikan pengaruh penerapan model pembelajaran (model pembelajaran penemuan masalah, pembelajaran berbasis masalah, dan pembelajaran berbasis proyek) terhadap sikap religius siswa. Kajian menggunakan pendekatan kuantitatif dengan sampel berjumlah 120 siswa SMP di Kecamatan Bantan. Pengumpulan data menggunakan angket dengan 72 pertanyaan. Analisis data menggunakan regresi linear berganda. Hasil kajian menunjukkan bahwa penerapan model pembelajaran yang memiliki frekuensi sangat tinggi adalah model pembelajaran penemuan dan pembelajaran proyek. Model pembelajaran berbasis masalah memiliki frekuensi tinggi. Model pembelajaran yang memiliki pengaruh paling besar terhadap karakter religius siswa adalah model pembelajaran penemuan dengan nilai sig $0.000<0.05$ dan nilai thitung 5.38 $>1.98$. Urutan kedua yaitu model pembelajaran berbasis proyek dengan nilai sig $0.001<0.05$ dan nilai t hitung 3.32 $>1.98$. Model pembelajaran berbasis masalah berada pada urutan ketiga dengan nilai sig $0.01<0.05$ dan nilai t hitung $2.63>1.98$.
\end{abstract}

Kata Kunci: pendidikan karakter, pendidikan kewarganegaraan, model pembelajaran penemuan, model pembelajaran berbasis masalah, model pembelajaran berbasis proyek

\section{PENDAHULUAN}

Studi yang dilakukan Centre of Strategic and International Studies (CSIS) pada tahun 2012, menyatakan bahwa toleransi beragama orang Indonesia tergolong rendah (Hermawati dkk, 2016: 106). Berdasarkan hasil dari penelitian yang dilakukan oleh
Pusat Penelitian Kebijakan Pendidikan dan Kebudayaan (Puslitjakdikbud), Badan Penelitian dan Pengembangan, Kementerian Pendidikan dan Kebudayaan (Kemendikbud), terdapat siswa yang cenderung menolak Ketua OSIS yang berbeda agama (Suryowati, 
2017). Komisi Nasional Perlindungan Anak mencatat bahwa aksi tawuran antar pelajar di seluruh pelosok negeri ini pada tahun 2011 mencapai 339 kasus dengan korban meninggal dunia mencapai angka 82 orang. Angka tersebut meningkat cukup signifikan 165 persen dari 128 kasus pada tahun 2010 (Sarah, 2014: 186). Fenomena di atas menunjukkan bahwa agama adalah satu identitas yang seringkali dikambinghitamkan dalam berbagai konflik yang terjadi di dalam masyarakat. Hal ini menunjukkan bahwa karakter religius individu khususnya tentang pemahaman toleransi antarumat beragama baik di dalam masyarakat maupun di lingkungan sekolah masih rendah. Masyarakat seakan terlalu mudah untuk terprovokasi dengan isu-isu yang belum tentu jelas kebenaranya. Asumsi tersebut mengindikasikan bahwa tujuan pendidikan untuk mewujudkan pribadi peserta didik yang beriman dan bertakwa kepada Tuhan Yang Maha Esa belum sepenuhnya terwujud.

Pendidikan karakter menjadi perhatian pemerintah dengan berbagai program salah satunya melalui Kementerian Pendidikan dan Kebudayaan pada tahun 2016 dengan membentuk Gerakan Penguatan Pendidikan Karakter (PPK). Secara eksplisit, pengembangan karakter religius melalui program Penguatan Pendidikan Karakter telah menjadi salah satu fokus kurikulum 2013. Integrasi penguatan pendidikan karakter dalam pembelajaran diatur dalam kurikulum 2013 dibebankan salah satunya melalui mata pelajaran PPKn. Karakter religius dalam pembelajaran PPKn menjadi tujuan penguasaan bagi peserta didik melalui standar penguasaan kompetensi yang termuat dalam kompetensi inti 1 yaitu, ketaatan beribadah, berperilaku syukur, berdoa sebelum dan sesudah melakukan kegiatan dan toleransi dalam beribadah.

Nilai religius yang perlu ditekankan dalam Pendidikan Kewarganegaraan adalah menciptakan warga negara yang dapat hidup berdampingan secara harmonis dalam keberagaman. Materi pembelajaran PPKn mengenai harmonis dalam keberagaman dalam kurikulum 2013 tertuang dalam kompetensi dasar yaitu, menghargai sikap toleransi dan harmoni keberagaman dalam kehidupan bermasyarakat, berbangsa, dan bernegara Indonesia dijabarkan menjadi, siswa menunjukkan sikap memelihara hubungan baik dengan sesama umat beragama yang berbeda-beda, tanggung jawab, peduli, toleransi, dan gotong royong dalam pembelajaran (Kemendikbud 2015: 220). Dengan mengajarkan nilai religius, siswa akan mampu memahami perbedaan tradisi keagamaan dari sudut ontologis, epistemologis, sosiologis, serta moral dasar. Siswa akan mengeksplorasi melalui pendekatan tradisi untuk memahami perbedaan, yaitu kemampuan yang lebih baik untuk memahami dan berkomunikasi dengan sesama meskipun memiliki asumi dasar yang berbeda baik bersifat religius maupun nonreligius (Wexler, 2002: 1201).

Pembentukan religius dipengaruhi oleh dua faktor utama yaitu faktor internal (kesadaran, motivasi dan kemauan) dan faktor eksternal (keluarga, sekolah dan masyarakat). Kedua faktor tersebut akan memiliki peran yang berbeda, hanya saja tetap saling berkaitan dalam upaya membentuk religius (Yusuf, 2004: 136-146). Sekolah memiliki peran untuk memperkuat nilainilai karakter positif yaitu, etika kerja, sikap hormat, tanggung jawab, kejujuran dan sebagainya. Sedangkan tugas keluarga adalah menetapkan fondasi dan sekolah membangun di atasnya (Lickona, 2012:77).

Peran sekolah dalam pembentukan karakter juga didukung beberapa aspek yang salah satunya pemilihan model pembelajaran. Pemilihan model pembelajaran yang tepat tentu harus dilakukan guru secara cermat dengan memperhatikan kebutuhan peserta didik di kelas. Upaya guru dalam penentuan model pembelajaran di kelas harus dilakukan guru dengan cara menginternalisasikan nilai-nilai karakter yang diharapkan dalam pelaksanaan pembelajaran. Hal ini diperkuat oleh pendapat Ada beberapa 
model pembelajaran yang dianjurakan dalam kurikulum 2013 yang merupakan suatu bentuk pembelajaran yang memiliki nama, ciri, sintaks, pengaturan, dan budaya. Model pembelajaran yang dikembangkan dalam PPKn yaitu pembelajaran penemuan, pembelajaran penyelidikan, pembelajaran berbasis masalah, dan pembelajaran berbasis proyek. Beberapa model tersebut tentu sangat sejalan dengan tujuan dari pembelajaran PPKn yang memfokuskan pada partisipasi aktif peserta didik. selain itu melalui pembelaajran ppkn harus dapat mengembangkan ketiga kompetensi kewarganegaraan. yang meliputi pengetahuan kewarganegaraan, keterampilan kewarganegaraan dan karakter kewarganegaraan (Bransons, 1998:5).

Pendidikan Kewarganegaraan mengajarkan karakter privat dan public. Karakter privat bersumber dari diri sendiri sementara public menyangkut hubungan dengan orang banyak. Religius dalam pendidikan Kewarganegaraan menekankan kepada bagaimana orang-orang religius dapat hidup secara berdampingan tanpa melepaskan identitas mereka sebagai umatberagama. Dari subnilai yang dijelaskan dalam PPK maka dapat di identifikasikan karakter public yaitu, cinta damai, toleransi cinta damai, menghargai perbedaan kyakinan, kerjasama antarpemeluk agama, dan mencintai lingkungan.

Naim (2011: 124) mengungkapkan bahwa nilai religius adalah peghayatan dan implementasi dari ajaran agama dalam kehidupan sehari-hari. Religiusitas memiliki tiga dimensi utama seperti yang dijelaskan dalam PPK yaitu dimensi hubungan dengan tuhan (taat menjalankan ibadah), hubungan dengan sesama manusia (toleransi), dan hubungan dengan lingkungan (cinta lingkungan). Dimensi hubungan dengan tuhan (El-Menouar, 2014: 61-63) membagi aspek religius yaitu: dimensi keyakinan (ideologis), dimensi peribadatan atau praktik agama (ritualistik), dimensi penghayatan (eksperiensial), dimensi pengamalan (konsekuensial), dimensi pengetahuan agama (intelektual). Sesungguhnya pendidikan karakter bertujuan untuk membentuk setiap pribadi menjadi insan manusia yang mempunyai nilai-nilai yang utama sebagai dasar karakter yang baik sesuai dengan nilai yang berlaku di masyarakat, nilai-nilai yang utama tersebut berasal dari ajaran agama, kearifan lokal, dan falsafah bangsa (Samsuri, 2011: 11).

Subjek Pendidikan Agama dan Pendidikan Kewarganagaraan meskipun memiliki dasar sistem nilai yang berbeda. Namun, kedua subjek pendidikan ini memiliki potensi signifikan untuk pengembangan nilai-nilai demokrasi dan identitas budaya kaum muda, yang membuka ruang untuk pendidikan antar budaya melalui proses mengembangkan, menghargai, dan memperkuat pluralisme budaya dan toleransi (Klemenovic \& Zukovic, 2013: 471). siswa secara bersamaan membangun rasa hormat dan memperoleh kompetensi yang dibutuhkan untuk hidup berdampingan dengan budaya yang berbeda. Siswa diberi kesempatan untuk mengembangkan kemampuan komunikasi yang konstruktif, toleransi terhadap pandangan dan perilaku yang berbeda, kesadaran akan tanggung jawab individu dan kolektif, pemahaman akan identitas budaya dan budaya dalam interaksi dengan identitas budaya dunia lainnya. Belajar untuk keragaman dan pembelajaran untuk kepentingan bersama harus dianggap sebagai model yang khusus dan yang universal dapat hidup berdampingan secara merata (Hasall \& Roebben, 2006: 448).

Intinya, dalam menciptakan kondisi untuk memahami dan menerima keragaman dengan mengadopsi nilai-nilai agama yang akan berkorelasi positif dengan prinsip-prinsip toleransi, pluralisme, dan multikulturalisme. Berdasarkan argumen yang disebutkan di atas, nampaknya dibenarkan untuk mengharapkan kedua subjek berada dalam fungsi demokratisasi pendidikan, pemodelan komunitas sekolah sebagai kosmos mikro masyarakat dan dalam fungsi pengembangan nilai-nilai kemanusiaan 
universal (Klemenovic \& Zukovic, 2013: 471).

Wexler (2002: 1200) menjelaskan bahwa siswa yang religius akan memiliki keterampilan penalaran intelektual penting untuk membantu siswa untuk berpartisipasi dalam kehidupan demokratis. Siswa dapat mempertimbangkan dengan moral dan etika dasar dengan landasan yang berbeda. Siswa yang religius juga dapat menganalisis, mengevaluasi, dan mengartikulasikan posisi pada isu publik dari dalam paradigma fundamental yang sangat berbeda. Pemahaman dan komunikasi ini akan difasilitasi terlepas dari apakah perbedaan itu bersifat religius atau nonreligius. Siswa akan mengerti bagaimana berkomunikasi dengan warga negara yang memiliki perbedaan pandangan yang menyangkut masalah toleransi.

Kurikulum 2013 menjelaskan bahwa pendidikan karakter dalam program terpadu salah satunya dibebankan kepada mata pelajaran PPKn. Pendidikan karakter dalam Mata pelajaran PPKn tertuang dalam KI 1 dan KI 2 yang harus dicapai dalam pembelajaran agar siswa memiliki kompetensi sikap sepiritual dan sosial untuk menjadi warga negara yang baik. menurut pendapatnya Somantri (Cholisin 2000:1.8), memberikan pengertian PPKn adalah Program pendidikan yang berisi demokrasi politik, yang diperluas dengan sumber-sumber pengetahuan lainnya, melalui pendidikan di sekolah, masyarakat, orang tua, yang kesemuanya itu diproses untuk melatih pelajar-pelajar berpikir kritis, analitis, dan bertindak demokratis dalam mempersiapkan hidup demokratis dengan berlandaskan Pancasila dan UUD 1945. Berbeda dengan pendapat di atas Pendidikan Kewarganegaraan diartikan sebagai penyiapan generasi muda (siswa) untuk menjadi warga negara yang memiliki pengetahuan, kecakapan, dan nilai-nilai yang diperlukan untuk berpartisipasi aktif dalam masyarakatnya (Samsuri, 2011: 28).

Pengintegrasian karakter religius dalam pembelajaran maka, di tetapkan oleh kemendikbud dalam kurikulum 2013 dalam capaian KI 1. Penilaian sikap spiritual (KI 1) siswa dalam kurikulum 2013 secara formal hanya di bebankan kepada pendidikan agama dan PPKn. Dengan demikian aspek sikap untuk mata pelajaran Pendidikan Agama dan Budi Pekerti dan PPKn dibelajarkan secara langsung (direct teaching) maupun tidak langsung (indirect teaching) yang memiliki dampak instruksional (instructional effect) dan memiliki dampak pengiring (nurturant effect). Sedangkan untuk mata pelajaran lain, tidak terdapat KD pada KI-1 dan KI-2 (Kemendikbud 2017b: 15). Dalam hal ini, penilaian sikap lebih ditujukan untuk membina perilaku dalam rangka pembentukan karakter peserta didik. Kompetensi sikap spiritual (KI-1) yang akan diamati adalah menerima, menjalankan, dan menghargai ajaran agama yang dianutnya. Contoh penjabaran indikator sikap spiritual adalah ketaatan beribadah, berperilaku syukur, berdoa sebelum dan sesudah melakukan kegiatan, toleransi dalam beribadah (Kemendikbud, 2017c:6-7).

Pembelajaran PPKn pada Kurikulum 2013 menggunakan pendekatan saintifik atau pendekatan berbasis proses keilmuan, dengan strategi pembelajaran kontekstual. Pendekatan saintifik dapat menggunakan beberapa model pembelajaran yang merupakan suatu bentuk pembelajaran yang memiliki nama, ciri, sintaks, pengaturan, dan budaya. Model pembelajaran yang dikembangkan dalam PPKn yaitu discovery learning, inquiry learning, problem-based learning, dan project- based learning.

Model pembelajaran penemuan (discovery learning) dan pembelajaran penyelidikan (inquiry learning)

Discovery learning dan inquiry learning berorientasi pada penemuan, peserta didik dituntut untuk menemukan sesuatu. Biasanya sesuatu yang ditemukan itu adalah konsep, artinya dengan belajar penemuan, anak-anak tidak diberi tahu terlebih dahulu konsepnya, dan setelah mereka mengamati, menanya, menalar, dan mencipta serta mencoba 
mereka akhirnya menemukan konsep itu. Sementara dalam modul materi pelatihan kurikulum 2013 dijelaskan bahwa tahap pelaksanaan model belajar penemuan sebagai berikut (Kemendikbud 2014 51-52).

1. Stimulus (memberikan pertanyaan atau menganjurkan siswa untuk mengamati gambar maupun membaca buku mengenai materi). Guru memberikan rangsangan kepada siswa dengan memberikan pertanyaan-pertanyaan, anjuran membaca buku, dan aktifitas belajar lainya mengenai materi yang akan ditemukan oleh siswa.

2. Problem statement (memberikan kesempatan kepada siswa untuk mengidentifikasi sebanyak mungkin masalah yang relevan dengan bahan pelajaran, kemudian memilih dan merumuskannya dalam bentuk hipotesis).

3. Data collection (memberikan kesempatan kepada siswa mengumpulkan informasi), Siswa diberikan kesempatan mengumpulkan informasi yang relevan untuk membuktikan hipotesis yang telah dirumuskan sebelumnya dari berbagai sumber.

4. Data processing (mengolah data yang telah diperoleh oleh siswa), Data yang diperoleh dari kegiatan pengumpulan data selanjutnya diklasifikasikan, diolah, diacak dan dikatagorisasikan untuk membentuk konsep dan generalisasi.

5. Verifikasi (mengadakan pemeriksaan secara cermat untuk membuktikan benar tidaknya hipotesis), Siswa melakukan pembuktian hipotesis dengan mehubungkan data yang diperoleh secara cermat. Kegiatan ini akan berjalan lancer ketika guru memberikan kesempatan kepada siswa untuk menemukan konsep, teori, atau pemahaman melalui contoh-contoh dalam kehidupanya.

6. Generalisasi (mengadakan penarikan kesimpulan). Tahap ini adalah kegiatan yang dilakukan untuk menarik kesimpulan yang dapat dijadikan prinsip umum dan berlaku untuk permasalahan yang sama berdasarkan hasil verifikasi. Siswa harus memeperhatikan pentingnya penguasaan pelajaran berdasarkan dasari pengalaman sesorang dan pentingnya generalisasi dari pengalaman yang ada.

Problem based learning merupakan metode pembelajaran yang mendorong siswa untuk menerapkan pemikiran kritis, kemampuan memecahkan masalah, dan pengetahuan konten untuk masalah dan isu-isu di dunia nyata (Marzuki \& Basariah, 2017: 395). Hong (2007:4) dan Filipenko \& Naslun (2016:4) memandang bahwa dalam problem based learning guru harus memberikan permasalahan dari dunia nyata kepada siswa untuk dipecahkan bersama. Pada saat membahas dan menjawab masalah, siswa harus terlibat dalam kegiatan nyata misalnya mengobservasi, mengumpulkan data, dan menganalisis bersama siswa lain dalam kelompok atau di dalam kelas.

Model PBL memiliki beberapa langkah pada implementasinya dalam proses pembelajaran, langkah-langkah PBL menurut Kemendikbud (2014: 58-59) sebagai berikut.

1. Orientasi siswa pada masalah Implementasi atau penggunaan strategi pembelajaran berbasis masalah harus dimulai dari membangun kesadaran kritis peserta didik akan adanya masalah yang akan dipecahkan. Pada tahap ini, guru dapat menunjukkan adanya gap atau kesengjangan antara realitas yang terjadi dengan idealitas atau yang dikehendaki

2. Mengorganisasi siswa untuk belajar. Guru membantu siswa mendefinisikan dan mengorganisasikan tugas belajar yang berhubungan dengan masalah tersebut. Guru mendorong siswa untuk merumuskan suatu masalah terkait dengan fenomena yang diamatinya. Membimbing pengalaman 
individual/kelompok. Guru mendorong siswa untuk mengumpulkan informasi yang sesuai, melaksanakan eksperimen untuk mendapatkan penjelasan dan pemecahan masalah. baik secara individu maupun kelompok, dengan membaca berbagai referensi, pengamatan lapangan, wawancara, dan sebagainya

3. Mengembangkan dan menyajikan hasil karya.

Guru membantu siswa dalam merencanakan dan menyiapkan karya yang sesuai seperti laporan, dan membantu siswa untuk berbagi tugas dengan temannya. Siswa menciptakan artifak (hasil karya) dan pameran.

4. Menganalisis dan mengevaluasi proses pemecahan masalah.

Guru membantu siswa untuk melakukan refleksi atau evaluasi terhadap penyelidikandan proses yang dilakukan. guru juga selalu mengajak siswa untuk merefleksikan materi pembelajaran yang sedang dipelajari dengan pola hidup sehari-hari, sehingga siswa terbiasa bersyukur dan menjaga diri. Project Based Learning (PjBL) adalah model pembelajaran yang menggunakan proyek/kegiatan sebagai inti pembelajaran (Kemendikbud, 2014:45). Siswa melakukan eksplorasi, penilaian, interpretasi, sintesis, dan informasi untuk menghasilkan berbagai bentuk hasil belajar. Pembelajaran berbasis proyek merupakan model belajar yang menggunakan masalah sebagai langkah awal dalam mengumpulkan dan mengintegrasikan pengetahuan baru berdasarkan pengalamannya dalam beraktifitas secara nyata. Langkah operasional PjBL dalam proses pembelajaran sebagai berikut.

1. Penentuan pertanyaan mendasar (Start With the Essential Question)

Pembelajaran dimulai dengan pertanyaan esensial, yaitu pertanyaan yang dapat memberi penugasan siswa dalam melakukan suatu aktivitas. Mengambil topik yang sesuai dengan realitas dunia nyata dan dimulai dengan sebuah investigasi mendalam dan topik yang diangkat relevan untuk para siswa.

2. Mendesain perencanaan proyek (Design a Plan for the Project)

Perencanaan berisi tentang aturan main, pemilihan aktivitas yang dapat mendukung dalam menjawab pertanyaan esensial, dengan cara mengintegrasikan berbagai subjek yang mungkin, serta mengetahui alat dan bahan yang dapat diakses untuk membantu penyelesaian proyek.

3. Menyusun jadwal (Create a Schedule) Pengajar dan siswa secara kolaboratif menyusun jadwal aktivitas dalam menyelesaikan proyek. Aktivitas pada tahap ini diantaranya: (1) membuat timeline untuk menyelesaikan proyek, (2) membuat deadline penyelesaian proyek, (3) membawa siswa agar merencanakan cara yang baru, (4) membimbing siswa ketika membuat cara yang tidak berhubungan dengan proyek, dan (5) meminta siswa untuk membuat penjelasan (alasan) tentang pemilihan suatu cara.

4. Memonitor siswa dan kemajuan proyek (Monitor the Students and the Progress of the Project)

Pengajar bertanggung jawab untuk melakukan monitor terhadap aktivitas siswa selama menyelesaikan proyek. Monitoring dilakukan dengan cara menfasilitasi siswa pada setiap Proses.

5. Menguji hasil (Assess the Outcome) Penilaian dilakukan untuk membantu pengajar dalam mengukur ketercapaian standar, berperan dalam mengevaluasi kemajuan masing- masing siswa, memberi umpan balik tentang tingkat pemahaman yang sudah dicapai siswa, membantu pengajar dalam menyusun strategi pembelajaran berikutnya.

6. Mengevaluasi pengalaman (Evaluate the Experience)

Pada akhir proses pembelajaran, pengajar dan siswa melakukan refleksi terhadap aktivitas dan hasil proyek yang sudah dijalankan. Proses refleksi dilakukan baik secara individu maupun kelompok. Pada tahap ini siswa 
diminta untuk mengungkapkan perasaan dan pengalamanya selama menyelesaikan proyek.

\section{METODE}

Metode penelitian menggunakan pendekatan kuantitatif dengan metode ex post facto. Penelitan ini dilakukan di Sekolah Menengah Pertama Negeri sekecamatan Bantan yang terdiri atas SMPN 1 Bantan dan SMPN 3 Bantan pada Bulan Juni 2018 sampai dengan Bulan Juli 2018. Penerapan Kurikulum 2013 di kecamatan bantan baru efektif dilaksanakan di dua sekolah tersebut dan hanya berlaku untuk kelas 2 .

Populasi yang digunakan dalam penelitian ini adalah seluruh siswa kelas 2 SMPN 1 Bantan sebanyak 60 orang dan SMPN 3 Bantan sebanyak 60 orang. Peneliti menggunakan sampling jenuh dalam mengambil reponden dari kelas 8 masing-masing sekolah sebanyak 120 orang menggunakan angket. Validasi angket dilakukn melalui penilaian ahli yang relevan (expert judgment).

Pengumpulan data menggunakan angket dengan 13 pertanyaan untuk indikator penerapan model pembelajaran penemuan masalah, 14 pertanyaan untuk indikator penerapan model pembelajaran berbasis masalah, 13 pertanyaan untuk indikator penerapan model pembelajaran berbasis proyek, dan 32 pertanyaan untuk indikator sikap religius.

Teknik analisis data yang digunakan adalah teknik analisis regresi linier beganda untuk mengukur perbandingan skor regresi sehingga dapat diketahui model pembelajaran dan pola asuh yang berpengaruh besar terhadap karakter religius siswa.

\section{HASIL DAN PEMBAHASAN}

Deskripsi Data Variabel Penerapan Model Pembelajaran dan Karakter Religius

Data penerapan dari model pembelajaran diambil dengan angket diberikan kepada siswa untuk mengungkap setiap kegiatan langkah pembelajaran yang dilakukan di dalam kelas. Pertanyaan untuk model pembelajaran penemuan menggunakan 13 pertanyaan dengan indikator kegiatan pembelajaran mulai dari: (1) stimulus, (2) problem statement, (3) data collection, (4) data processing, (5) verifikasi, dan (5) generalisisasi. Model pembelajaran berbasis masalah menggunakan 14 pertanyaan dengan indikator kegiatan pembelajaran mulai dari: (1) orientasi siswa pada masalah, (2) mengorganisasi siswa untuk belajar, (3) membimbing pengalaman individual/kelompok, (4) mengembangkan, menganalisis dan mengevaluasi proses pemecahan masalah. Model pembelajaran berbasis proyek menggunakan indikator yaitu: (1) penentuan pertanyaan mendasar, (2) mendesain perencanaan proyek, (3) menyusun jadwal, (4) memonitor siswa dan kemajuan proyek, (5) menguji hasil, dan (6) mengevaluasi pengalaman.

Data karakter religius diambil melalui angket dengan 32 pertanyaan kepada siswa dengan menanyakan intensitas siswa terhadap indikator perilaku yang menunjukkan religius yang baik, yaitu: (a) ketaatan beribadah, (b) berperilaku syukur, (c) berdoa sebelum dan sesudah melakukan kegiatan, dan (d) toleransi dalam beribadah.

Tabel 1. Diskripsi Katagorisasi Model Pembelajaran dan Karakter Religius

\begin{tabular}{lccccccccc}
\hline & \multicolumn{1}{c}{ Katagori } & Discovery & PBL & PJBL & $\begin{array}{c}\text { Karakter } \\
\text { religius }\end{array}$ & Discovery & PBL & PJBL & $\begin{array}{c}\text { Karakter } \\
\text { religius }\end{array}$ \\
\cline { 2 - 10 } & 1 & 1 & 1 & - & .8 & 0.8 & 0.8 & - \\
\hline Rendah & 6 & 18 & 10 & 13 & 5.0 & 15.0 & 8.3 & 10.8 \\
\hline Sedang & 21 & 69 & 45 & 41 & 17.5 & 57.5 & 37.5 & 34.2 \\
\hline Tinggi & 92 & 32 & 64 & 66 & 76.7 & 26.7 & 53.3 & 55.0 \\
\hline Sangat tinggi & 120 & 120 & 120 & 120 & 100.0 & 100.0 & 100.0 & 100.0 \\
\hline Total & & & & & & & & \\
\hline
\end{tabular}


Berdasarkan uraian hasil kategorisasi dalam tabel 1 untuk model pembelajaran penemuan, responden memberikan kecenderungan kategorisasi yang sangat tinggi dengan frekuensi 92 responden dengan persentase $76,7 \%$. Model pembelajaran berbasis masalah responden memberikan kecenderungan kategorisasi tinggi yang memiliki frekuensi 69 responden dengan persentase $57,5 \%$ dari seluruh responden. Responden model pembelajaran berbasis proyek memberikan kecenderungan frekuensi kategorisasi sangat tinggi yaitu 64 responden dengan persentase 53,3\%. Kesimpulannya penerapan model pembelajaran di sekolah berada dalam kategori baik. Sementara itu, untuk karakter religius memberikan kecenderungan sangat tinggi dengan frekuensi 66 responden dengan persentase $55 \%$. Dengan demikian dapat disimpulkan bahwa tingkat karakter religius siswa dalam katagori sangat baik.

\section{Pengaruh model pembelajaran PPKn terhadap karakter religius siswa}

Hasil pengujian hipotesis menujukkan bahwa model pembelajaran PPKn memberikan pengaruh positif dan signifikan terhadap karakter religius siswa. Hal ini dibuktikan melalui tabel annova dengan nilai signifikansi 0,000 yang lebih kecil daripada taraf signifikansi yang ditentukan yakni 0,05 . Ketiga model pembelajaran ini menggunakan pendekatan saintifik yang menciptakan pengalaman belajar yang berorientasi pada siswa.

Tabel 2. Hasil pengolahan data regresi model pembelajaran PPKn terhadap karakter religius siswa.

\begin{tabular}{llll}
\hline No. & Model pembelajaran & Sig & t \\
\hline 1. & Pembelajaran penemuan & 0.000 & 5.38 \\
\hline 2. & $\begin{array}{l}\text { Pembelajaran berbasis } \\
\text { masalah }\end{array}$ & 0.01 & 2.63 \\
\hline 3. & $\begin{array}{l}\text { model pembelajaran berbasis } \\
\text { proyek }\end{array}$ & 0.001 & 3.32 \\
\hline
\end{tabular}

Pada tabel 2 menunjukkan bahwa model pembelajaran yang memiliki pengaruh paling besar adalah model pembelajaran penemuan dengan nilai sig $0.000<0.05$ dan nilai t hitung 5.38 $>1.98$. Urutan kedua yaitu model pembelajaran berbasis proyek dengan nilai sig $0.001<0.05$ dan nilai $t$ hitung $3.32>1.98$. Model pembelajaran berbasis masalah berada pada urutan ketiga dengan nilai sig $0.01<0.05$ dan nilai $t$ hitung $2.63>1.98$.

Hasil uji hipotesis yang menunjukkan adanya pengaruh positif model pembelajaran terhadap sikap religius, dapat dilihat dari nilai thitung merupakan nilai yang positif bukan negatif. Dengan adanya pengaruh positif tersebut berarti, semakin baik model pembelajaran yang diterapkan maka semakin baik pula karakter religius siswa. Model pembelajaran harus menciptakan pengalaman belajar bagi siswa yang mampu memberikan kemudahan agar pembelajaran dan nilai-nilai yang diharapkan dapat diserap dengan baik. Table 3. sumbangan relatif dan efektif model pembelajaran PPKn terhadap karakter religius siswa

\begin{tabular}{llcc}
\hline No. & Model & SE & SR \\
\hline 1 & Discovery & 12.03 & 37.22 \\
\hline 2 & Problem & 2.21 & 6.83 \\
\hline 3 & Proyek & 2.87 & 8.86 \\
\hline \multicolumn{3}{l}{ Pembentukan karakter religus siswa }
\end{tabular}
melalui model belajar penemuan menunjukkan hasil yang lebih efektif yaitu sebesar $12 \%$ lebih besar dari kedua model pembelajaran lainya yaitu PBL sebesar 2,21\% dan PJBL sebesar $2.87 \%$.

Data implementasi model pembelajaran di sekolah menunjukkan bahwa responden memberikan kencenderungan model pembelajaran penemuan pada kategorisasi sangat tinggi dengan frekuensi 92 responden dengan persentase $76.7 \%$. Model belajar berbasis masalah responden memberikan kencenderungan pada kategorisasi tinggi yang memiliki frekuensi 69 responden dengan persentase $57.5 \%$. Model pembelajaran berbasis proyek responden memberikan kencenderungan pada kategorisasi sangat 
tinggi frekuensi 64 responden dengan persentase $53.3 \%$. Sehingga dapat disimpulkan bahwa maka model pembelajaran yang diterapakan di sekolah dalam katagori baik.

Model pembelajaran penemuan mendorong pembuktian sendiri oleh siswa membuat siswa semakin yakin dengan apa yang dilihat (Toharudin, 2011:54). Keyakinan dapat menumbuhkan rasa syukur terhadap Tuhan Yang Maha Esa. Pembelajaran penemuan memberi kesempatan kepada siswa untuk berinteraksi antar siswa untuk mendapatkan pemahaman yang lebih baik melalui proses dan eksplorasi. Hal tersebut dapat memunculkan sikap untuk terus mencari penjelasan dan menghargai pendapat orang lain, serta memiliki sikap terbuka dengan gagasan baru, berpikir kritis, jujur, dan kreatif. Mendukung pernyataan di atas, maka pendidikan kewarganegaraan dalam memberikan pemahaman nilai pada siswa dengan mengajak mereka untuk mengalami dan menemukan dengan caranya sendiri. Pembelajaran akan lebih bermakna ketika siswa dapat membandingkan dan menghubungkan pembelajaran di kelas dengan fakta yang terjadi di lingkungan sekitarnya. Konsep Pendidikan Kewarganegaraan menujukkan bahwa warga negara harus dididik agar dapat mengembangkan kompetensi sebagai masyarakat yang dapat berpartisipasi dalam kehidupan bernegara (Jotia, 2011:137). Proses pembelajaran harus dirancang menggunakan metode yang menciptakan suasana partisipatif, demokratis, salah satunya melalui pembelajaran penemuan. Metode belajar penemuan akan menawarkan kebebasan intelektual bagi para pelajar dan kebebasan untuk menerapkan pikiran pada situasi sehingga menemukan solusi dan dengan demikian, para pembelajar akan mengembangkan tingkat kreativitas yang lebih tinggi untuk menjadi pemikir yang reflektif, dan untuk mengembangkan toleransi dan juga bekerja sama dalam dialog.

Proses oreintasi siswa pada masalah guru dapat membuat kasus yang berhubungan intoleransi antar umat beragama di Indonesia (Rizki, zubaidah, \& kumalasari, 2015:8). Di balik kesadaran akan adanya masalah dimaksudkan, guru mampu menanamkan nilai-nilai karakter seperti religius, rasa ingin tahu, belajar keras, semangat kebangsaan dan cinta tanah air. Guru perlu mengorganisasikan proses belajarn siswa dengan menciptakan kondisi kelompok belajar yang heterogen, berinteraksi antar anggota, komunikasi yang efektif, tutor sebaya, dan sebagainya. Guru memonitor dan mengevaluasi kerja masing-masing kelompok untuk menjaga kinerja dan dinamika kelompok selama pembelajaran. Guru dapat membahas kasus-kasus intoleransi dalam kehidupan beragama di Indonesia. Cara seperti ini perserta didik akan mampu membangun kesadaran bagaimana seharusnya bertindak secara benar sesuai dengan norma yang berlaku sehingga mampu membangun karakter secara tidak langsung. Guru juga selalu mengajak siswa untuk merefleksikan materi pembelajaran yang sedang dipelajari dengan pola hidup sehari-hari, sehingga siswa terbiasa bersyukur dan menjaga diri. Perlakuan yang sama tentang penyampaian nasehat di akhir pembelajaran dan reflesksi diri sudah merupakan anjuran dari Kurikulum 2013 yang merupakan pokok dari PBL maupun pendekatan ilmiah sendiri.

Problem based Learning (PBL) berpengaruh terhadap tumbuhnya kesadaran toleransi dalam menyikapi perbedaan. Model pembelajaran yang dikembangkan bersifat multidimensi dan multidisiplin, dan mampu membekali transfer ilmu pengetahuan, peresapan nilai-nilai dan akhlak dalam ranah praktik, sehingga menumbuh kembangkan kearifan pengetahuan, kesadaran sikap dan perilaku peserta didik terhadap keragaman (Muhibbin dan Sumardjoko 2018:7).

Nilai karakter yang dapat diterapkan dalam pembelajaran Project Based Learning adalah pemahaman terkait konsep karakter yang diintegrasikan pada materi yang akan disampaikan selama pembelajaran 
berlangsung dan melalui keteladanan guru (Arisona 2016: 108). Contohnya dalam sub materi menghargai sikap toleransi dan harmoni keberagaman dalam kehidupan bermasyarakat, berbangsa, dan bernegara Indonesia. Siswa dapat dilibatkan dalam proyek secara berkelompok di dalam kelas. Kegiatan diskusi yang dilakukan di kelas menjadi simulasi yang diharapkan karakter yang tertanam dapat diaplikasikan dalam kehidupan sehari-hari. Hal lain yang bisa dilakukan melalui Project Based Learning untuk menumbuhkan karakter dapat dilakukan dengan memberikan keteladanan, guru dapat mencontohkan dan memberikan respon

\section{SIMPULAN}

1. Model pembelajaran penemuan penerapannya sangat sesuai yang dipilih oleh 92 (76,7\%) responden. Model pembelajaran berbasis masalah responden memberikan kecenderungan sesuai dengan jumlah pemilih 69 (57,5\%) responden. Responden model pembelajaran berbasis proyek jumlah pemilih terbanyak 64 $(53,3 \%)$ responden. Rata-rata keseluruhan berkaitan dengan penerapan model pembelajaran di sekolah berada dalam kategori baik.

2. Model pembelajaran yang memiliki pengaruh paling besar adalah model pembelajaran penemuan dengan nilai sig

\section{DAFTAR RUJUKAN}

Arisona, R. D. 2016. Project Based Learning Untuk Membangun Karakter Fiqh Al-Biah Pada Pembelajaran IPS. Al Ulya, 1(1), 98-110.

Branson, M.S. 1999. Belajar Civic Education" dari Amerika (terjemah). Yogyakarta: LKIS dengan Dukungan The Asia Foundation (TAF).

Cholisin. 2000. IKN - PKN. Jakarta. Universitas Terbuka.

El-Menouar, Y. 2014. The five dimensions of muslim religiosity. results of an empirical study. Method, Data, terhadap sikap siswa dalam proses diskusi di dalam kelas. Keteladanan seperti ini juga dapat menguatkan karakter. Tugas proyek sangat bermanfaat untuk menghasilkan pemahaman yang menyeluruh dan reintegrasi (Harmin \& Melanie, 2012:337). Selain itu tugas proyek juga dapat membentuk siswa yang bisa mengandalkan diri sendiri, selalu ingin tahu dan mandiri. Pembelajaran kelompok digunakan apabila materi pembelajaran lebih mengembangkan konsep pokok/sub-pokok bahasan yang sekaligus mengembangkan aktivitas sosial, sikap, nilai, kerjasama, dan aktivitas dalam pemecahan masalah melalui kelompok belajar siswa.

$0.000<0.05$ dan nilai thitung $5.38>1.98$. Urutan kedua yaitu model pembelajaran berbasis proyek dengan nilai sig 0.001 $<0.05$ dan nilai t hitung $3.32>1.98$. Model pembelajaran berbasis masalah berada pada urutan ketiga dengan nilai sig $0.01<0.05$ dan nilai thitung 2.63 $>1.98$. Model yang paling efektif dalam pembentukan karakter religus siswa adalah model pembelajaran penemuan yaitu dengan SE sebesar 12\% lebih besar dari kedua model pembelajaran lainya yaitu PBL sebesar 2,21\% dan PjBL sebesar $2.87 \%$.

Analyses, 8(1), 53-78. https://doi. org/10.12758/mda.2014.003.

Filipenko, M. \& Naslun, J. A. 2016. Problem Based Learning in Teacher Education. New York, London: Springer International Publishing.

Harmin., Toth, M.M. 2012. Inpiring Active Learning: A complete Handbook For Today's Teacher. Terjemahan: Betharia Annisa Ismayasari. Jakarta: PT. Indeks.

Hasall., A. \& Roebben, B. 2006. Intercultural and interfaith dialogue through 
education. Religius Education, 101(4), 443-452.

Hermawati, R., Paskarina, C., \& Runiawati, N. 2016. Toleransi antar umat beragama di kota Bandung. Jurnal Antropologi, 1(2), 105-124.

Hong, J.C. 2007. The Comparison of Problem Based Learning (Pmbl) Model And Project Based Learning (Ptbl) Model. International Conference on Engineering Education.

Jotia., A., L. 2011. Educating for Democratic Engagement in Botswana's Democracy: Challenges of Promoting Democratic Education. Journalof Social Development in Africa. 26(1), 135-160.

Kemendikbud. 2014. Materi Pelatihan Implementasi Kurikulum 2013 tahun 2014. Jakarta. Badan Pengembangan Sumber Daya Manusia Pendidikan dan Kebudayaan dan Penjamin Mutu Pendidikan.

Kemendikbud. 2015. Pendidikan Pancasila dan Kewarganegaraan : buku guru untuk SMP/MTS Kelas IX. Jakarta: Kementerian Pendidikan dan Kebudayaan.

Kemendikbud. 2016. Pembelajaran dan Penilaian Mata Pelajaran PPKn SMA/ SMK/MA/MAK. Jakarta. Kementerian Pendidikan dan Kebudayaan.

Kemendikbud. 2017. Konsep dan pedoman penguatan pendidikan karakter. Buku 1. Jakarta.

Kemendikbud. 2017. Panduan Penilaian oleh Pendidik dan Satuan Pendidikan SMA. jakarta: Direktorat Jenderal Pendidikan Dasar dan Menengah.

Kemendikbud. 2017. Silabus mata pelajaran Sekolah Menengah Pertama/Madrasah
Tsyanawiyah (SMP/MTs) Mata Pelajaran Pendidikan Pancasila Dan Kewarganegaraan (PPKn) kurikulum 2013. Jakarta: Kementerian Pendidikan Dan Kebudayaan.

Klemenovic, J., \& Zukovic, S. 2013. Civic education and religius education in the function of democratization of education in the Republic of Serbia. Zbornik Instituta Za Pedagoska Istrazivanja, 45(2), 464-481. https:// doi.org/10.2298/ZIPI1302464K.

Lickona, T. 2012. Mendidik untuk Membentuk Karakter. Bandung. Bumi Aksara.

Muhibbin, A., \& Sumardjoko, D. B. 2016. Model pembelajaran Pendidikan Kewarganegaraan berbasis isu-isu kontroversial di media massa untuk meningkatkan sikap demokrasi mahasiswa dan implikasinya bagi masyarakat madani. Jurnal Pendidikan Ilmu Sosial, 26(1), 1412-3835.

Marzuki, \& Basariah. 2017. Pengaruh model problem-based learning dan project citizen dalam pembelajaran PKN terhadap kemampuan berpikir kritis dan karakter disiplin siswa. Cakrawala Pendidikan, 36(3), 382-400. https:// doi.org/10.21831/cp.v36i3.14675.

Naim , N. 2012. Character building. Yogyakarta: Ar-Ruzz Media.

Rizqi, HK, Zubaidah, Kumalasari. 2015. Pengaruh Problem Based Learning (PBL) terhadap Motivasi dan Hasil Belajar Siswa Kelas VIII SMP Brawijaya Smart School Malang. SKRIPSI Jurusan Biologi-Fakultas MIPAUM http://jurnal-online.um.ac. id/data/artikel/ 